\title{
Two new species of Liocranidae (Arachnida: Aranei) from the Caucasus and northern Iran
}

\author{
Ава новых вида миокранид (Arachnida: Aranei: Liocranidae) \\ с Кавказа и из северного Ирана
}

\author{
Alireza Zamani ${ }^{1}$, Yuri M. Marusilk ${ }^{2,3}$ \\ А. Замани ${ }^{1}$ Ю.М. Марусик ${ }^{2,3}$ \\ ${ }^{1}$ Zoological Museum, Biodiversity Unit, University of Turku, FI-20014, Finland. E-mail: zamani.alireza5@gmail.com
${ }^{2}$ Institute for Biological Problems of the North RAS, Portovaya Str.18, Magadan 685000, Russia. E-mail: yurmar@mail.ru
${ }^{2}$ Институт биологических проблем Севера ДВО РАН, Ул. Портовая, 18, Магадан 685000, Россия.
${ }^{3}$ Department of Zoology \& Entomology, University of the Free State, Bloemfontein 9300, South Africa.
}

KEY WORDS: Araneae, Armenia, Azerbaijan, fauna, Hyrcanian region, spiders. КЛЮЧЕВЫЕ СЛОВА: Araneae, Азербайджан, Армения, Иран, Гиркан, паук.

ABSTRACT. Two new species of Liocranidae, Agroeca angirasu sp.n. ( $\sigma^{\top}$, Iran) and Mesiotelus caucasicus sp.n. ( $\sigma^{\top}+$, Armenia, Azerbaijan, Iran) are described and illustrated based on material collected in the Caucasus and Hyrcanian region in northern Iran. The distribution records of both species are mapped.

How to cite this paper: Zamani A., Marusik Yu.M. 2021. Two new species of Liocranidae (Arachnida: Aranei) from the Caucasus and northern Iran // Arthropoda Selecta. Vol.30. No.4. P.557-564. doi: 10.15298/ arthsel.30.4.12

РЕЗЮМЕ. Описаны и проиллюстрированы два новых вида пауков семейства Liocranidae Agroeca angirasu sp.n. (О', Иран) и Mesiotelus caucasicus sp.n. (Оํ, Азербайджан, Армения, Иран). Точки находок новых видов показаны на карте.

\section{Introduction}

Liocranidae Simon, 1897 is a moderate-sized family of spiders currently comprising 298 extant species in 34 genera distributed worldwide [WSC, 2021]. The family is poorly-defined, lacking distinct synapomorphies and appears to be polyphyletic, with its intergeneric relationships remaining mostly unresolved [Jocqué, Dippenaar-Schoeman, 2006]. In this paper, we contribute to the taxonomy of Liocranidae in the Caucasus and the Middle East by describing two new species from Armenia, Azerbaijan and northern Iran. Currently, Liocranidae is represented by five species in three genera in Iran [Zamani et al., 2021; Zamani, Marusik, 2021], five species in four genera in Azerbaijan, and only one recently reported species from Armenia [Marusik, Guseinov, 2003; Otto, 2020; Zarikian et al., 2021].

\section{Material and methods}

Specimens were photographed using a Canon EOS 7D camera attached to an Olympus SZX16 stereomicroscope and a JEOL JSM-5200 scanning electron microscope at the Zoological Museum of the University of Turku. Digital images were montaged using CombineZP and edited using CorelDraw graphic design softwares. Lengths of palp and leg segments were measured on the dorsal side and listed as: total length (femur, patella, tibia, metatarsus [missing on palp], tarsus).

ABBREVIATIONS: Eyes: ALE - anterior lateral eye, AME - anterior median eye, PLE - posterior lateral eye, PME — posterior median eye. Palp: RTA — retrolateral tibial apophysis. Spination: $\mathrm{Fe}$ - femur, $\mathrm{Pa}$ - patella, $\mathrm{Ti}-$ tibia, Mt - metatarsus.

DEPOSITORIES: Muséum d'histoire naturelle, Genève, Suisse (MHNG); the Manchester Museum of the University of Manchester, United Kingdom (MMUE); the Zoological Museum of Moscow University, Russia (ZMMU); Zoological Museum of the University of Turku, Finland (ZMUT).

\section{Taxonomy}

Family Liocranidae Simon, 1897

Genus Agroeca Westring, 1861

COMMENTS. Currently, two species of this genus are known in Iran [Zamani et al., 2021] and three species have been reported in the Caucasus [Otto,2020; Mikhailov, 2021]: A. cuprea Menge, 1873, A. lusatica (L. Koch, 1875) and A. maculata L. Koch, 1879 (the latter not reported from Iran). The first two species are well known, while for the third one no detail figures of the male palp exist in the literature. Furthermore, there are no publications illustrating the expanded male palp's complex embolus (except for A. dentigera Kulczyński, 1913, see figs 29a-b in Grimm [1986] and A. istia Biurrun et Barrientos, 2021, see fig. 3C in Biurrun et al. [2021]). Therefore, besides figures of the new species 


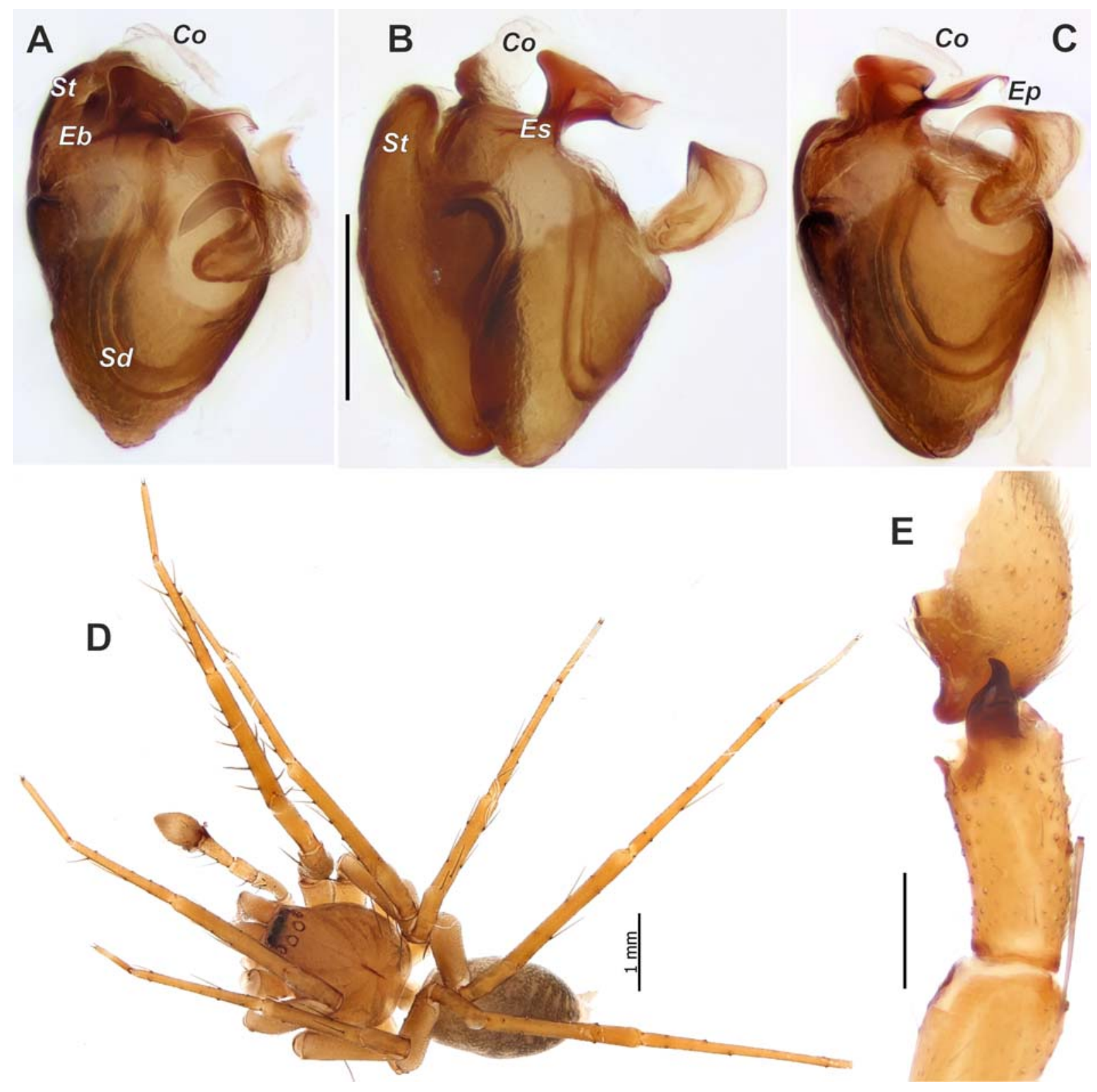

Fig. 1. Holotype male of Agroeca angirasu sp.n. A-C - bulb, antero-ventral, ental and ventral; D - habitus, dorsal; E - palpal tibia and cymbium showing the shape of RTA. Scale $0.2 \mathrm{~mm}$, if not otherwise indicated. Abbreviations: $\mathrm{Co}$ - conductor, $E b-$ embolus' base, $E p$ - embolus proper, $S d$ - sperm duct, $S t$ - subtegulum.

Рис. 1. Самец (голотип) Agroeca angirasu sp.n. А-C - бульбус, антеро-латериально, пролатерально и вентрально; D габитус, сверху; Е - голень пальпы и цимбиум, показана форма отростка голени. Масштаб 0,2 мм, если не указано иначе. Сокращения: $C o-$ кондуктор, $E b-$ основание эмболюса, $E p-$ эмболюс, $S d-$ семенной канал, $S t-$ субтегулюм.

described below, we have also provided comparative figures of A. proxima (O. Pickard-Cambridge, 1871).

\section{Agroeca angirasu sp.n.}

Figs 1, 2A-D.

TYPE MATERIAL. Holotype $\sigma^{7}$ (MHNG), IRAN: Golestan Province: Shast Kalateh, $36^{\circ} 46^{\prime} \mathrm{N}, 54^{\circ} 11^{\prime} \mathrm{E}, 2018$ (R. Rafiei-Jahed).

COMPARATIVE MATERIAL. Agroeca proxima: FINLAND: Korpo Island: $2 \sigma^{\top} \sigma^{\top}$ (ZMUT), Åvensor, 28.06.-26.08.1968 (P. Lehtinen) (Fig. 2E-F).
ETYMOLOGY. The new species is named after Anguirus (Hepburn: Angirasu), a fictional monster which first appeared in Godzilla Raids Again (1955) and has a covering of spikes over his carapace, referring to the distinct rows of six pairs of long spines on the tibiae I and II of the holotype specimen.

COMMENTS. Even though the spination pattern of the new species is similar to those of Scotina Menge, 1873 (610 pairs of ventral spines on tibia I and 5-9 pairs on tibia II), because of the following characters we decided to describe it in Agroeca: 1) it is larger than any known Scotina species 


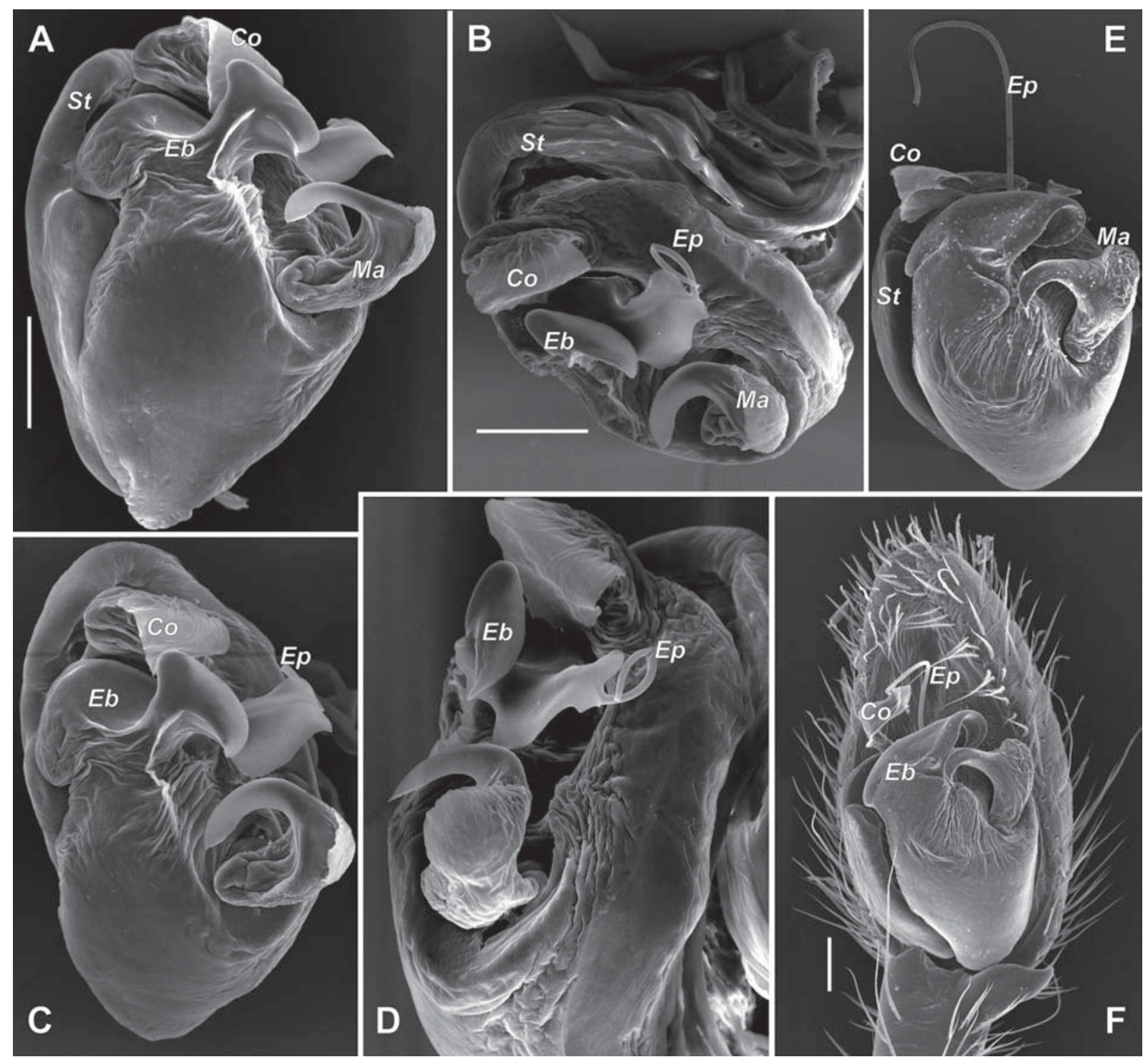

Fig. 2. SEM images of the male palps of Agroeca angirasu sp.n. (A-D) and A. proxima (E-F). A, E - bulb, ventral; B - bulb, anterior; C-D - bulb, antero-ectal and antero-antero-ectal; F — palp, ventral. Scale $0.1 \mathrm{~mm}$. Abbreviations: $C o-$ conductor, $E b-$ embolus' base, $E p$ - embolus proper, $M a$ - median apophysis, $S t$ - subtegulum.

Рис. 2. Пальпа самца Agroeca angirasu sp.n. (А-D) и A. proxima (E-F). А, Е - бульбус, снизу В - бульбус, спереди; C-D бульбус, спереди-снаружи и спереди-спереди-снаружи; F - пальпа, вентрально. Масштаб 0,1 мм. Сокращения: Со - кондуктор, $E b$ - основание эмболюса, $E p$ - эмболюс, $M a$ - медиальный отросток, $S t$ - субтегулюм.

(2.0-3.5 mm, Nentwig et al. [2021]), and it has 2) smaller subtegulum, similar to those of Agroeca spp., 3) relatively larger median apophysis, 4) modified base of embolus (vs. not modified in Scotina spp.), and 4) different eye formula. Photograph of the whole palp is not provided because both palps of the holotype were expanded.

DIAGNOSIS. The new species differs from congeners by having 6 pairs of ventral tibial spines on leg I (vs. 2 pairs, cf. Grimm [1986]; Almquist [2006]) and by the shape of the embolic complex: base of embolus $(E b)$ with stem $(E s)$, ribbon-shaped twisted and not tapering proximal part of embolus, and short filamentous embolus proper $(E p)$, shorter than ribbon-shaped part ( $v s$. embolic base without stalk, embolus gradually tapering, and embolus proper long, longer than ribbon-shaped part, cf. Fig. 2E-F).
DESCRIPTION. Male. Habitus as in Fig. 1D. Total length 4.20. Carapace 1.90 long, 1.50 wide. Eye sizes: ALE: 0.15, AME: 0.13, PLE: 0.13, PME: 0.12. Carapace, sternum, chelicerae, maxillae and labium light brown, without any pattern. Abdomen dorsally light grayish with lighter chevron markings, ventrally light gray without any patterns. Legs the same color as carapace. Measurements of leg segments: I: $7.35(1.05,1.56,1.96,0.85,1.93)$, II: 6.70 (0.98, $1.48,1.66,0.80,1.78)$, III: $6.21(1.56,0.71,1.28,1.68,0.98)$, IV: $8.86(2.01,0.84,2.08,2.64,1.29)$. Spination (excluding Mt III and IV): I: Fe: 2d, 1v, Ti: 12v, Mt: 1pl, 6v; II: Fe: 2d, Ti: 12v, Mt: 6v, 1pl; III: Fe: 2pl, 3d, 1rl, Pa: 1d, Ti: 1pl, 1d, 1rl, 6v; IV: Fe: 1pl, 3d, 1rl, Pa: 1d, Ti: 2pl, 2d, 1rl, 5v.

Palp as in Figs 1A-C, E, 2A-D; tibia long, 2.5 times longer than wide, 1.2 times shorter than cymbium, RTA as 
long as tibia, wide at the base; bulb subtriangular, with subtegulum $(S t)$ as long as tegulum; median apophysis as long as wide; conductor $(\mathrm{Co})$ broad, about as wide as long, bent horizontally; embolus complex, basal part with distinct stem (Es, Fig. 1B), ribbon-shaped twisted proximal part, with abrupt tip; embolus proper (Ep) filamentous, about as long as median apophysis.

Female. Unknown.

DISTRIBUTION. Known only from the type locality in Golestan Province, northern Iran (Fig. 6).

\section{Genus Mesiotelus Simon, 1897}

COMMENTS. This genus currently comprises 15 nominal species of which 14 are distributed in the Palaearctic, from the western Mediterranean to eastern China but unreported between eastern Uzbekistan and Henan [WSC, 2021]. Mesiotelus pococki Caporiacco, 1949 was described from Kenya, known from a single taxonomic entry and judging by the illustration of epigyne, most likely misplaced within the genus. Five species are known only from females, including M. pococki, and one species, M. patricki Zamani et Marusik, 2021 is known only by male. The genus has never been a subject of revision or review in a large region. While identifying female specimens from Armenia, we recognized that they are similar to M. scopensis Drensky, 1935 and $M$. deltshevi Naumova, 2020 (the latter known only from females). Extensive search of material collected in the Caucasus yielded male and female material collected in the same locality in Azerbaijan. Comparison of epigynes of Caucasian specimens revealed that they differ from the two aforementioned species, and that their male palps differ from the Iranian endemic M. patricki. All species found in eastern Mediterranean and Central Asia have rather similar epigynes.

NOTE. Here, we have proposed the new terms "prolateral tegular apophysis $(P t)$ " and "retrolateral tegular apophysis $(R t)$ " for describing palpal morphology. Although the retrolateral apophysis is located between the median and the prolateral apophyses, we are using the term "median apophysis" because it is homologous to the median (=tegular) apophysis present in other members of the RTA-clade. Prolateral and retrolateral tegular apophyses are not preoccupied terms, and the morphology of the bulb in other Mesiotelus species has not been described in such detail before.

\section{Mesiotelus caucasicus sp.n. Figs 3-4, 5A-E.}

Mesiotelus sp.: Marusik, Guseinov, 2003: 36; Marusik et al., 2005: 41.

Mesiotelus cf. scopensis: Zarikian et al., 2021: in press

TYPE MATERIAL. Holotype $\sigma^{7}$ (ZMMU), AZERBAIJAN: Ismaiilli District: Xangah (=Khanakh Eng.), $40^{\circ} 51^{\prime} \mathrm{N} 48^{\circ} 08^{\prime} \mathrm{E}$, 30.09.2003 (E.F. Huseynov). Paratypes: $30^{7} \sigma^{7} 2$ 2 $9+$ (ZMMU), same data as for the holotype; 1 ( (MMUE), same locality, $700 \mathrm{~m}$, 19.06.2002 (ZMMU); 19 (ZMMU), Nakhchivan: Sharur Dist., Akhura, $39^{\circ} 34^{\prime} \mathrm{N} 45^{\circ} 11^{\prime} \mathrm{E}, 2.06 .2003$ (E.F. Huseynov). ARMENIA: Vayot Dzor Province: 1 ( (ZMMU) Gnishik R. canyon, rd. to Noravank Monastery, 39 $41^{\prime} 14.0^{\prime \prime} \mathrm{N} 45^{\circ} 13^{\prime} 21^{\prime \prime} \mathrm{E}, 1400 \mathrm{~m}, 10.05$. 2021 (Yu.M. Marusik); Kotayk Province: 2 우 (MMUE), env. of Solak Vill, 40 $28^{\prime} 24^{\prime \prime} \mathrm{N} 44^{\circ} 42^{\prime} 57^{\prime \prime} \mathrm{E}, 14.05 .2021$ (Yu.M. Marusik); 1 우 (ZMMU), Vokhchabert, $40^{\circ} 09^{\prime} 56^{\prime \prime} \mathrm{N} 4^{\circ} 38^{\prime} 59^{\prime \prime} \mathrm{E}, 15.05 .2021$ (Yu.M. Marusik); 9 우 (ZMMU), env. of Geghadir, 2 canyons nearby, $40^{\circ} 09^{\prime} \mathrm{N} 44^{\circ} 38^{\prime} \mathrm{E}, 15.05 .2021$ (Yu.M. Marusik). IRAN Mazandaran Province: 1 우 (MHNG), Razan, $36^{\circ} 12^{\prime} \mathrm{N} 52^{\circ} 08^{\prime} \mathrm{E}$, $1500 \mathrm{~m}, 8.07 .1975$ (A. Senglet).
ETYMOLOGY. The specific epithet refers to the distribution of the species in the Caucasus.

DIAGNOSIS. Female of new species is similar to those of $M$. scopensis and M. deltshevi, but can be differentiated from $M$. deltshevi by having relatively larger anterior epigynal pocket $(A p)$ (cf. Fig. 5A-E and $5 \mathrm{H}-\mathrm{I}$ ) and wider angle formed by foveal lateral margins $(\mathrm{Lm})$. Epigyne of the new species differs from those of $M$. scopensis by having straight lateral margins of the fovea ( $v s$. rounded). Male of M. caucasicus sp.n. differs from those of $M$. patricki by more elongated bulb, smaller median apophysis, subtegulum extended posteriorly over the tegulum and different course of sperm duct (cf. Fig. 4D and 4H).

DESCRIPTION. Male. Habitus as in Fig. 3B. Total length 5.1. Carapace 2.0 long, 1.7 wide. Chelicera 1.6 long. Eye sizes: ALE: 0.14, AME: 0.11, PLE: 0.1, PME: 0.09. Carapace, sternum, chelicerae, maxillae and labium light brown, without any pattern. Chelicera with 3 small promarginal and 3 large retromarginal teeth. Abdomen beige, with faint posterior chevron markings and 2 brown sigilla dorsally, with faint tracheal marks ventrally. Legs yellowish brown. Measurements of palp and leg segments: palp: 4.27 (1.5, $1.06,0.93,0.78)$, I: $11.16(2.85,1.42,2.94,2.6,1.35)$, II: $9.51(2.52,1.23,2.43,2.19,1.14)$, III: 7.83 (2.04, 0.93, 1.76, 2.08, 1.02), IV: $10.76(2.76,1.02,2.66,3.15,1.17)$. Spination (excluding Mt): I: Fe: 1pl, 1d, Ti: 4v; II: Fe: 1pl, 2d, Ti: 4v; III: Fe: 2pl, 2d, 2rl, Ti: 1pl, 1rl, 6v; IV: Fe: 1pl, 2d, 1rl, Ti: 2pl, 1rl, 4v.

Palp as in Figs 3C, G-I, 4A-G; 4.35 long (almost as long as body), femur longest, ca 1.4 times longer than patella, 1.6 times longer than tibia and almost 1.8 times longer than cymbium; tibia almost 5.5 times longer than wide, RTA as long as tibia's terminal width, with parallel margins in proximal $2 / 3$, and triangular in terminal $1 / 3$; cymbium elongate, 2.6 times longer than wide; with distinct tip as long as bulb's width; bulb 2 times longer than wide; subtegulum extended over the proximal edge of tegulum; tegulum with U-shaped sperm duct with 3 apophyses: median $(M a)$, prolateral $(P t)$ and retrolateral $(R t)$; median apophysis flexibly attached to the tegulum, with wide basal part, as wide as length of terminal part, terminal part almost cylindrical, about 5 times longer than wide; prolateral and retrolateral apophyses just extension of tegulum, both pointed; prolateral apophysis partly hides base of embolus; embolus (Em) originates at about 7:30 o'clock position, terminal (free) part flat, gradually tapering, in retrolateral view appears as thin tube.

Female (from type locality). Habitus as in Fig. 3A, F. Total length 4.88. Carapace 1.90 long, 1.50 wide. Eye sizes: ALE: 0.12, AME: 0.10, PLE: 0.12, PME: 0.09. Coloration as in male, without abdominal chevron pattern. Measurements of leg segments: I: $7.20(1.85,1.08,1.90,1.46,0.91)$, II: $6.57(1.85,0.86,1.69,1.30,0.87)$, III: $5.84(1.61,0.75$, $1.35,1.44,0.69)$, IV: $8.95(2.34,0.92,2.21,2.48,1.00)$. Spination (excluding Mt): I: Fe: 1pl, 2d, Ti: 4v; II: Fe: 2d, Ti: 4v; III: Fe: 1pl, 2d, Ti: 1pl, 2rl, 6v; IV: Fe: 1pl, 2d, 1rl, Ti: $1 \mathrm{pl}, 2 \mathrm{rl}, 5 \mathrm{v}$.

Epigyne as in Fig. 5A-E; about 1.3 times longer than wide; anterior pocket $(A p)$ wide, about 4 times smaller than foveal margin's maximal span; anterior (from $A p$ to lateral margin) and posterior parts equal in length; foveal margins straight, diverging anteriorly, forming an approximate angle of $55^{\circ}$; receptacles together with short copulatory ducts as long as wide, span of receptacle equal to maximal span of foveal margins. 

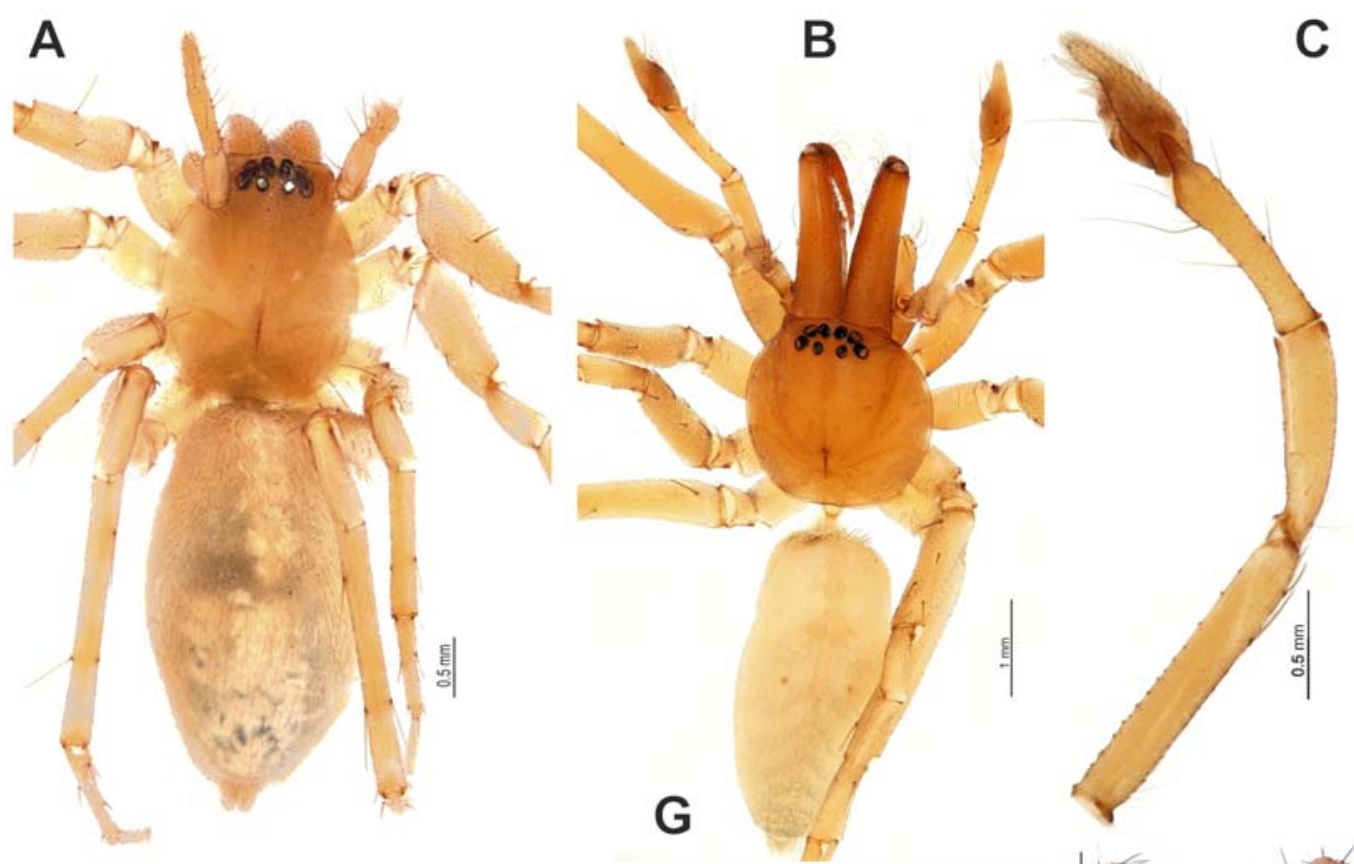

C
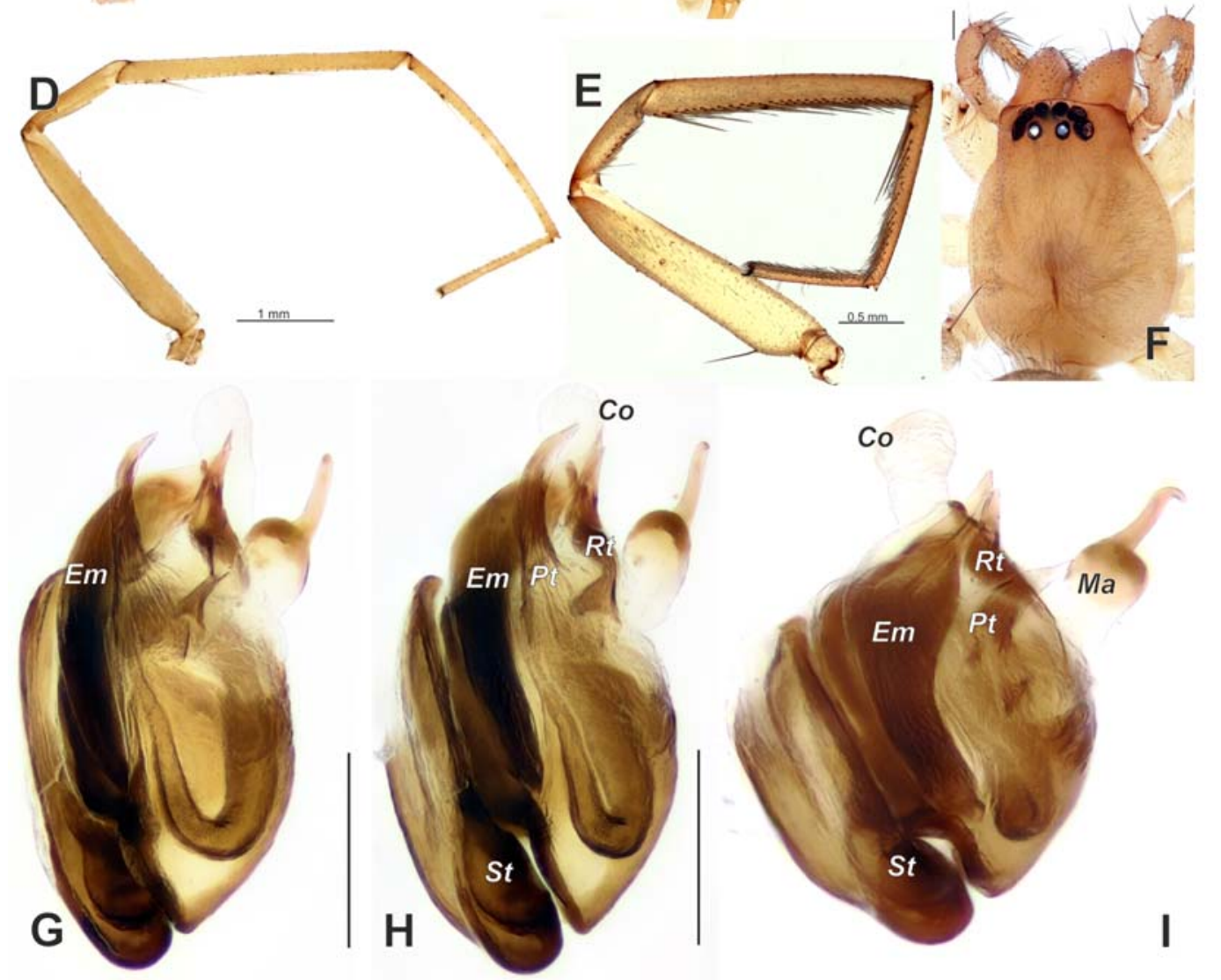

Fig. 3. Mesiotelus caucasicus sp.n. A-B - female and male habitus, dorsal; $\mathrm{C}$ - male palp, retrolateral; D-E - male and female leg I; F - female prosoma, dorsal; G-I - macerated and partly expanded bulb, ventro-prolateral, prolateral and antero-prolateral. A-D, G-I specimens from the type locality, E-F — from Armenia. Scale $0.2 \mathrm{~mm}$, if not otherwise indicated. Abbreviations: $\mathrm{Co}$ - conductor, $E m$ embolus, $M a$ - median apophysis, $P t, R t$ - prolateral and retrolateral tegular apophyses, $S t$ - subtegulum.

Pис. 3. Mesiotelus caucasicus sp.n. А-В - внешний вид самки и самца, сверху; С - пальпа самца, ретролатерально; D-E нога I самца и самки; F - головонпуль самки, сверху; G-I - мацерированный и немного вздутый бульбус, снизу-изнутри, изнутри и спереди-изнутри. A-D, G-I - экземпляры из типового локалитета, E-F - экземпляры из Армении. Масштаб 0,2 мм, если не указано иначе. Сокращения: Co - кондуктор, $E m$ - эмболюс, $M a$ - медиальный отросток, $P t, R t$ - пролатеральный и ретролатеральный тегулярные отростки, $S t-$ субтегулюм. 


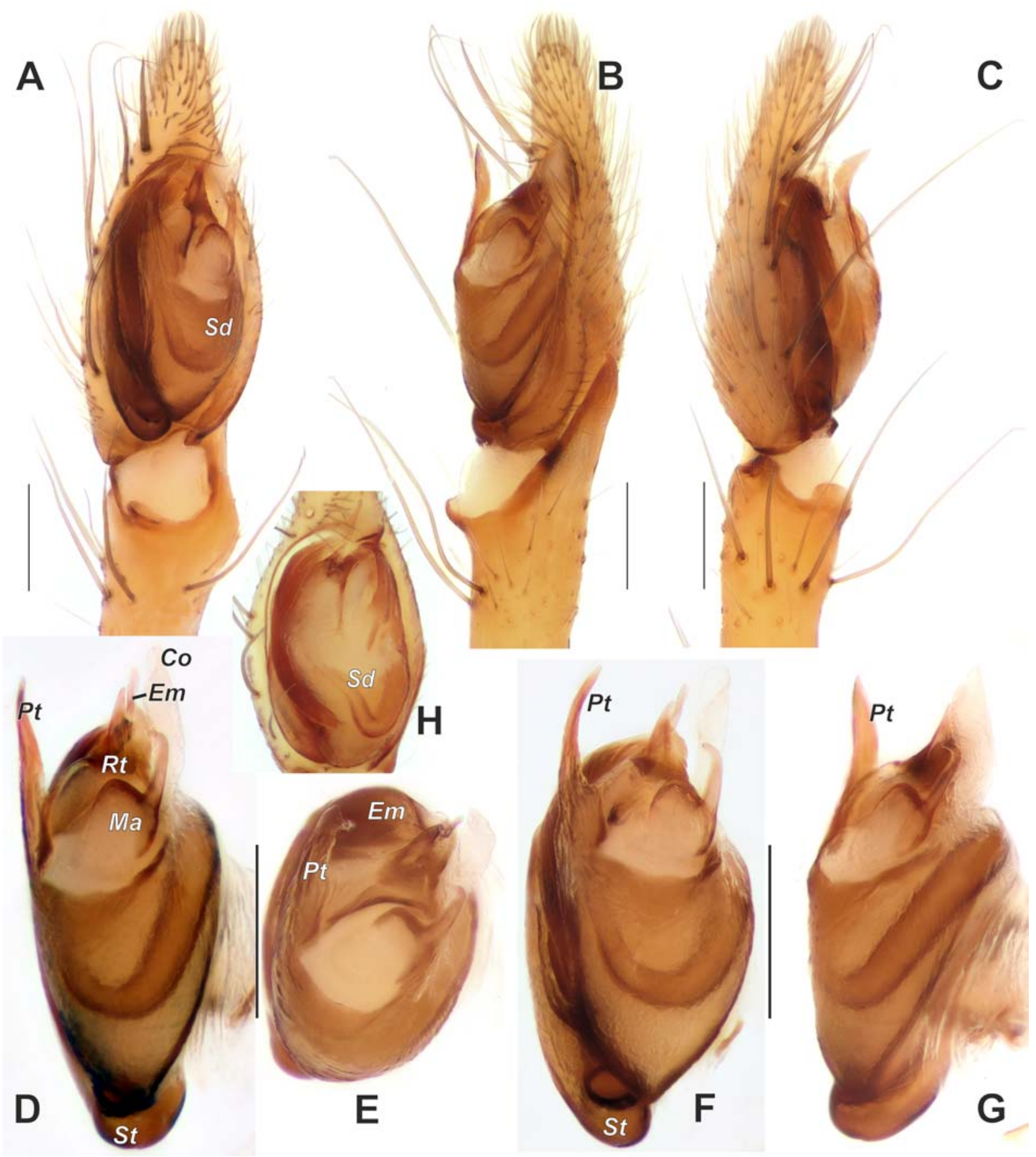

Fig. 4. Male palps of Mesiotelus caucasicus sp.n. (A-G) and M. patricki (H). A-C - terminal part of palp, ventral, retrolateral and prolateral; D-H - bulb, ventro-retrolateral, ventro-anterior, ventro-prolateral, dorso-retrolateral and ventral. Scale $0.2 \mathrm{~mm}$. Abbreviations: Co - conductor, Em - embolus, $M a$ - median apophysis, $P t, R t$ - prolateral and retrolateral tegular apophyses, $S d-$ sperm duct, $S t$ subtegulum.

Рис. 4. Пальпа самца Mesiotelus caucasicus sp.n. (А-G) и M. patricki (H). A-C - вершинная часть пальпы, снизу, ретро- и пролатерально; D-H - бульбус, вентро-ретролатерально, вентрально-спереди, вентро-пролатерально, дорзо-ретролатерально и вентрально. Масштаб 0,2 мм. Сокращения: $C o$ - кондуктор, Em - эмболюс, $M a$ - медиальный отросток, $P t, R t$ пролатеральный и ретролатеральный тегулярные отростки, $S d-$ семенной каналец, $S t-$ субтегулюм. 


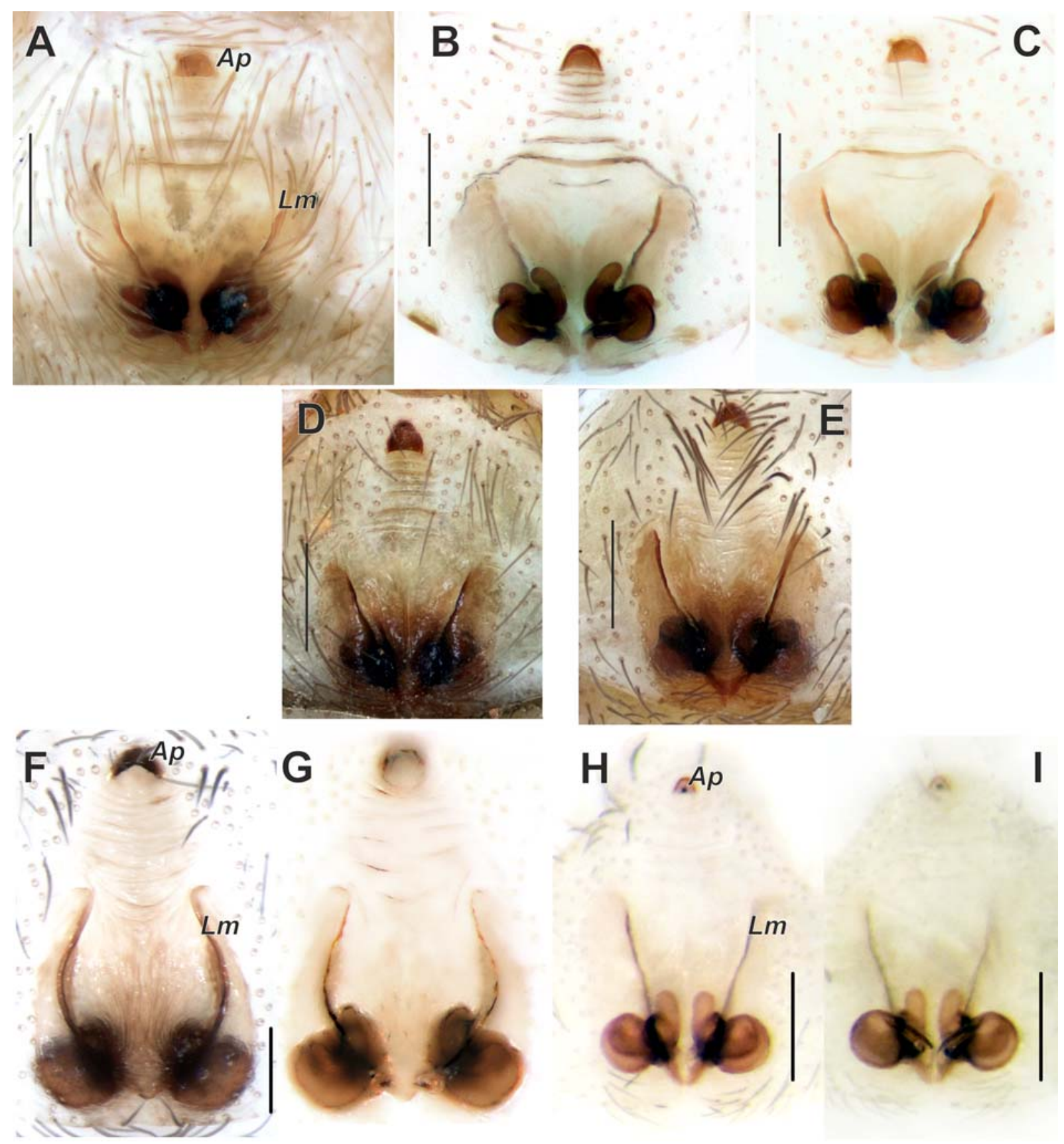

Fig. 5. Epigynes of Mesiotelus caucasicus sp.n. (A-E), M. scopensis ( $\mathrm{F}-\mathrm{G}$, from Bulgaria) and M. deltshevi (H-I, holotype from Albania). A, D-F - intact, ventral; C, H - macerated, ventral; B, G, I - macerated, dorsal. A-C - from type locality; D-E - from Armenia. F-I - courtesy of Maria Naumova. Scale $0.2 \mathrm{~mm}$. Abbreviations: $A p$ - anterior pocket, $L m$ - lateral margin.

Рис. 5. Эпигина Mesiotelus caucasicus sp.n. (А-Е), M. scopensis (F-G, из Болгарии) и M. deltshevi (Н-I, голотип из Албании). А, D-F - интактная, снизу; C, H - мацерированная, снизу; В, G, I - мацерированная, сверху. А-C — из типового локалитета; D-E из Армении. F-I - фото любезно предоставила Мария Наумова. Масштаб 0,2 мм. Сокращения: $A p$ - передний карман, $L m-$ боковые края. 


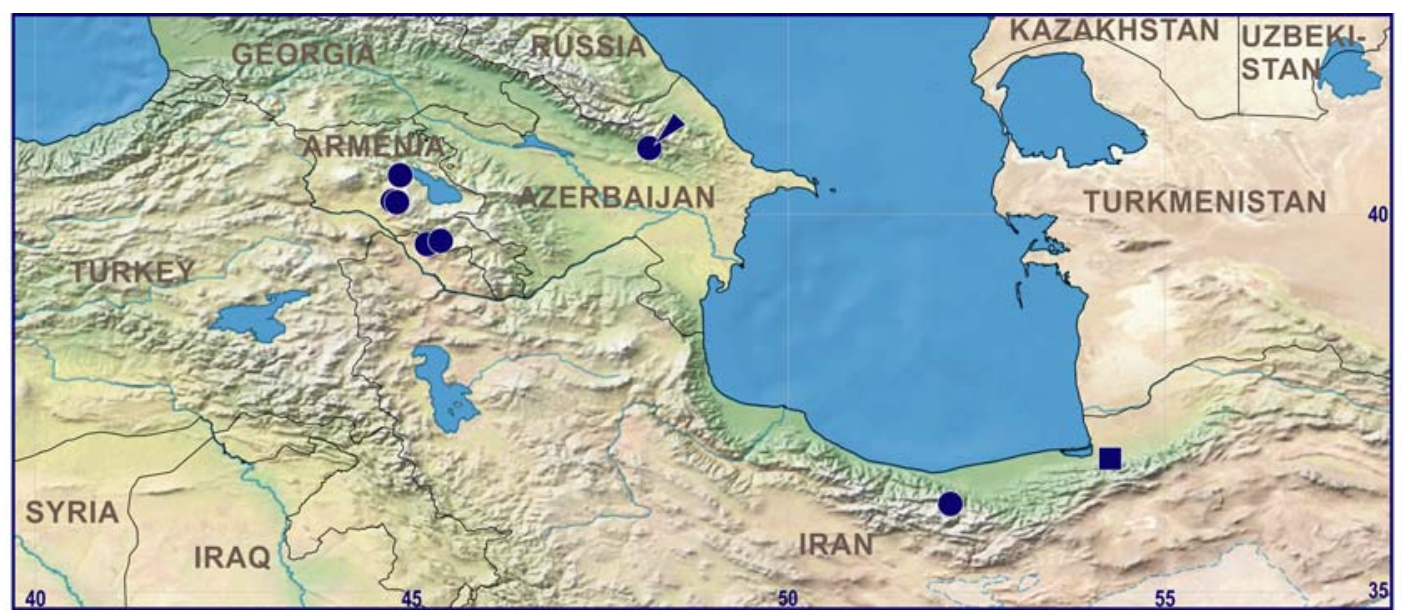

Fig. 6. Distribution records of Agroeca angirasu sp.n. (square) and Mesiotelus caucasicus sp.n. (circle). Arrow indicates the type locality of $M$. caucasicus sp.n.

Рис. 6. Точки находок Agroeca angirasu sp.n. (квадрат) и Mesiotelus caucasicus sp.n. (кружок). Стрелка показывает типовое местообитание $M$. caucasicus sp. n.

COMMENTS. Epigynes of Armenian specimens have slightly different proportions: they are relatively longer (1.6 times longer than wide vs. 1.3) and have foveal margins forming more acute angle (ca. $45^{\circ} v s .55^{\circ}$ ). We have considered these as intraspecific variations, as females collected in the same region have been observed to differ slightly in such proportions as well.

DISTRIBUTION. Known only from the listed localities in Armenia, Azerbaijan and northern Iran (Fig. 6).

Acknowledgements. We are grateful toward Razieh Rafiei-Jahed (Gorgan, Iran) for providing us with collected material, Maria Naumova (Sofia, Bulgaria) for the figures of epigynes of the holotype of Mesiotelus deltshevi and $M$ scopensis from Bulgaria, and Lionel Monod and Peter Schwendinger (MHNG) for sending us the material collected by A. Senglet in Iran. Maria Naumova and Jan Bosselaers (Beerse, Belgium) kindly reviewed the manuscript.

\section{References}

Almquist S. 2006. Swedish Araneae, part 2 - families Dictynidae to Salticidae // Insect Systematics \& Evolution, Supplement. Vol.63. P.285-601.

Biurrun G., Barrientos J.A., Baquero E. 2021. A new species of Agroeca Westring, 1861 from Navarra, Spain (Araneae: Liocranidae) // Zootaxa. Vol.4941. No.1. P.84-90. doi:10.11646/ zootaxa.4941.1.4
Grimm U. 1986. Die Clubionidae Mitteleuropas: Corinninae und Liocraninae (Arachnida, Araneae) // Abhandlungen des Naturwissenschaftlichen Vereins in Hamburg (NF). Bd.27. S.1-91.

Jocqué R., Dippenaar-Schoeman A.S. 2006. Spider families of the world. Tervuren: Musée Royal de l'Afrique Central. 336 p.

Marusik Yu.M., Guseinov E. 2003. Spiders (Arachnida: Aranei) of Azerbaijan. 1. New family and genus records // Arthropoda Selecta. Vol.12. No.1. P.29-46.

Marusik Yu.M., Guseinov E., Aliev H.A. 2005. Spiders (Arachnida: Aranei) of Azerbaijan 4. Fauna of Naxçivan // Arthropoda Selecta. Vol.13. No.3. P.135-149.

Nentwig W., Blick T., Bosmans R., Gloor D., Hänggi A., Kropf C. 2021. Spiders of Europe. Version 11.2021. Online at https:// www.araneae.nmbe.ch, accessed on 6.11.2021. https://doi.org/ $10.24436 / 1$

Otto S. 2020. Caucasian Spiders. A faunistic database on the spiders of the Caucasus. Version 10.2020. Internet: https:// caucasus-spiders.info/

WSC. 2021. World Spider Catalog. Version 22.5. Natural History Museum Bern, online at http://wsc.nmbe.ch, accessed on 27.09.2021.

Zamani A., Marusik Yu.M. 2021. A new genus and ten new species of spiders (Arachnida, Araneae) from Iran // ZooKeys. Vol.1054. P.95-126.

Zamani A., Mirshamsi O., Marusik Yu.M., Moradmand M. 2021. The Checklist of the Spiders of Iran. Version 2021, Online at http://www.spiders.ir

Zarikian N.A., Propistsova E.A., Marusik Yu.M. 2021. On spider families (Arachnida: Araneae) new to Armenia // Israel Journal of Entomology (in press)

Responsible editor K.G. Mikhailov 